

\section{Kalpataru}

Jurnal Sejarah dan Pembelajaran Sejarah

Volume 7, Nomor 1, Juli 2021

\section{Chief Editor}

Drs. Sukardi, M.Pd.

\section{Editor}

Dr. Muhamad Idris, M.Pd.

Eva Dina Chairunisa, M.Pd.

Jeki Sepriady, S.Pd.

\section{Reviewer}

Dr. Tahrun, M.Pd.

Drs. Supriyanto, M.Hum.

Dra. Retno Purwati, M.Hum.

Dr. Nor Huda Ali, M.Ag., M.A.

Dr. Budi Agung Sudarman, S.S., M.Pd.

Dr. Purmansyah, M.A.
(Universitas PGRI Palembang)

(Universitas Sriwijaya Palembang)

(Balai Arkeologi Sumatera Selatan)

(Masyarakat Sejarawan Indonesia Sumsel)

(Balai Bahasa Provinsi Sumatera Selatan)

(Universitas Muhammadiyah Palembang)

\footnotetext{
Alamat Redaksi

Program Studi Pendidikan Sejarah

Fakultas Keguruan dan IImu Pendidikan Universitas PGRI Palembang

Telp. 0711-510043

Email: jurnalkalpatarusejarah@gmail.com

Website: https://jurnal.univpgri-palembang.ac.id/index.php/Kalpa
} 


\section{Kalpataru}

JURNAL SEJARAH DAN

PEMBELAJARAN SEJARAH

Terbit dua kali setahun pada Juli dan Desember

Diterbitkan oleh:

Program Studi Pendidikan Sejarah Jurusan Pendidikan IPS

Fakultas Keguruan

dan IImu Pendidikan

Universitas PGRI Palembang

\section{DAFTAR ISI}

Nilai Budaya Masjid Jami' Sungai Lumpur Kelurahan II Ulu Palembang Sebagai Sumber Pembelajaran Sejarah Maya Susanti, Muhamad Idris, Aan Suriadi.....

Analisis Konsep Gender Dalam Undang-Undang Simbur Cahaya Sebagai Sumber Pembelajaran Sejarah Ruli Annisa, Muhamad Idris, Kabib Sholeh $10-18$

Perbedaan Model Pembelajaran Student Teams Achievement Divisions (STAD) dengan Model Pembelajaran Jigsaw Terhadap Hasil Belajar Siswa Pada Mata Pelajaran Sejarah di SMA Negeri 2 Mesuji

Taufik Sidiki Al-Haq, Nur Ahyani, Ida Suryani. 19-27

Pengaruh Pemanfaatan Media Youtube Terhadap Hasil Belajar Siswa Mata Pelajaran Sejarah di SMK PGRI 2 Palembang

Riska Anggraini, Nur Ahyani, Ida Suryani. $28-36$

Pengaruh Metode Pembelajaran Daring Terhadap Hasil Belajar Siswa Pada Mata Pelajaran Sejarah di Kelas XI IPA SMA Shailendra Palembang

Christina Leovita Saragih, Nur Ahyani, Aan Suriadi. $37-42$

Pengembangan Media Pembelajaran Digital Bukti-bukti Bangunan Masjid Kuno di Palembang Berbasis Android Varokah Widiyanti, Eva Dina Chairunisa, Ahmad Zamhari .

\section{Gambar Cover:}

Pohon Kalpataru

Candi Prambanan

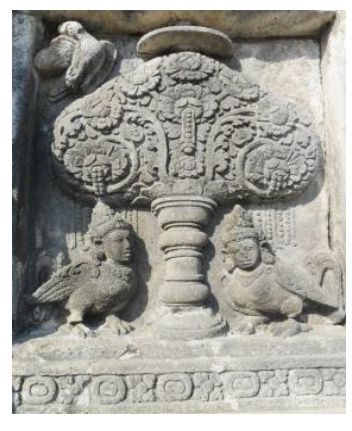

Koleksi: Muhamad Idris
Hubungan Jawa-Melayu Dalam Dunia Arsitektur Melayu Sumatera Selatan

Reyvaldi Uyun, Muhamad Idris, Ahmad Zamhari.

Kondisi Politik Orde Baru di Gorontalo Tahun 19681998

Ferrari Yuliawati S, Suryo Ediyono.

Nilai-nilai Sejarah dan Budaya Ikonografi Megalith di Lahat Sebagai Sumber Pembelajaran Sejarah Nasional Jainal Arifin, Sukardi, Dina Sri Nindiati.

Minat Siswa Terhadap Sejarah dan Budaya Palembang di SMA Negeri 15 Palembang

Febbi Astuti, Muhamad Idris, Kabib Sholeh. 77-82 


\title{
HUBUNGAN JAWA-MELAYU DALAM DUNIA ARSITEKTUR MELAYU SUMATERA SELATAN
}

\author{
Reyvaldi Uyun \\ Mahasiswa Program Pendidikan Sejarah FKIP Universitas PGRI Palembang \\ Email: aldialdisamsung@gmail.com \\ Muhamad Idris \\ Dosen Program Pendidikan Sejarah FKIP Universitas Pgri Palembang \\ Email: idrismuhamad1970@gmail.com \\ Ahmad Zamhari \\ Dosen Program Pendidikan Sejarah FKIP Universitas Pgri Palembang \\ Email: zamhariahmad1969@gmail.com
}

\begin{abstract}
ABSTRAK
Hubungan Jawa dengan Melayu telah berlangsung setidaknya sejak masa Kedatuan Sriwijaya. Hubungan ini mempengaruhi sistem yang ada di tanah Melayu, tepatnya di Sumatera Selatan. Termasuk dalam hal arsitektur di Sumatera Selatan. Arsitekur adalah sebuah karya seni manusia yang dibuat dalam merancang dan membangun sebuah bangunan atau ruang dengan sebaik mungkin. Penelitian ini menggunakan metode penelitian deskriptif kualitatif dengan cara mengumpulkan sumber-sumber data secara sistematis dan sumber data yang mendalam dan berhubungan. Pengumpulan data dilakukan dengan cara survei lapangan, wawancara mendalam, pencatatan dokumen dan studi pustaka. Dalam penelitian kualitatif, ada empat teknik mencapai keabsahan data, yaitu: kredibilitas, transferabilitas, auditabilitas (dipendabilitas), konfirmabilitas dan triangulasi. Hasil dari penelitian ini adalah bahwa adanya hubungan Jawa-Melayu dalam dunia arsitektur Melayu di Sumatera Selatan.
\end{abstract}

Kata Kunci: Hubungan Jawa-Melayu, Arsitektur Melayu Sumatera Selatan.

\section{A. PENDAHULUAN}

Indonesia adalah negara kepulauan terbesar di dunia. Indonesia memiliki lebih dari 17.000 pulau, di mana hanya sekitar 7.000 pulau yang berpenghuni. Kalimantan, Jawa, Sulawesi, Sumatera dan Papua merupakan pulau utama yang ada di Indonesia. Masyarakat Indonesia terdiri dari sekitar 300 suku, seperti suku Jawa, Sunda, Batak, Dayak dan Papua. Besarnya kekayaan budaya Indonesia membuat negara ini memiliki banyak peninggalan bersejarah baik arsitektur, budaya dan lainnya. Pulau Jawa merupakan pulau terbesar kelima dari +13.466 pulau yang ada di Indonesia, pulau Jawa didiami oleh suku atau penduduk asli yaitu suku Jawa. Namun, selain suku Jawa berbagai suku juga dapat dijumpai di pulau Jawa, di antaranya: suku Bawean, suku Osing, suku Tengger, suku Samin, suku Sunda, suku Cirebon, suku Betawi, suku Baduy, dan suku Banten (Farela, 2017:8).
Suku Jawa yang memang sudah terkenal dengan kekuatannya, yaitu sejak masa kerajaan Majapahit, di mana kerajaan ini sudah memiliki kekuatan militer dan persenjataan yang lengkap, mereka sudah mampu menganeksasi dan melakukan kerjasama berbagai tempat di Indonesia sampai keluar Indonesia yaitu kerajaan Melayu di Malaysia sekarang (Nurhidayah, 2019:1).

Suku Melayu merupakan suku asli dari Sumatera dan berkembang hampir keseluruh pulau Sumatera termasuk Sumatera bagian Selatan. Suku Melayu memiliki hubungan dengan bangsa luar dan dalam, termasuk suku Jawa. Sejarah yang tertulis jelas itu pada masa Sriwijaya dari Palembang dan Kerajaan Mataram Kuno masa dinasti Syailendra. Ditemukannya Prasasti Ligor B menguatkan teori hubungan antara Sriwijaya dengan Mataram Kuno itu benar adanya. Data 
mengenai Kerajaan Sriwijaya di Palembang dapat dilihat dari sumber teks bangsa asing yang dulu pernah ke Indonesia, seperti Cina, India, Thailand dan Arab (Faizaliskadiar, 1993). Jawa dan Melayu merupakan dua suku yang berbeda, namun keduanya memiliki kedekatan dan kesamaan yang begitu banyak. Hal ini dapat kita lihat dari berbagai kesamaan budaya dan adatnya, di antaranya seperti naskah Melayu dan Jawa yang digunakan untuk memperkenalkan tulisan (Jawi) Arab sebagai suatu cara untuk menyebarkan ilmu pengetahuan kepada penduduk di kepulauan Melayu (Idris, 2019).

Tidak hanya itu kedekatan antara Jawa dan Melayu juga terlihat dari peninggalan kebudayaan Melayu dan Jawa berupa dialeg dan adat istiadat Jawa yang masih digunakan oleh Melayu Palembang. Masyarakat Jawa dikenal sebagai masyarakat yang sangat toleran dengan budaya asing yang masuk ke wilayah kebudayaan Jawa. Orang Jawa memiliki kecakapan kultural dalam beradaptasi dengan budaya asing (Bakri, 2014). Palembang merupakan perpaduan antara kebudayaan Melayu dan Jawa. Keduanya larut menjadi satu dalam perkembangan Palembang, diikuti oleh local genius setempat yang kemudian dikenal sebagai kebudayaan Palembang (Hanafiah, 1995).

Kota Palembang yang merupakan ibukota dari Sriwijaya dikenal dengan bentuk arsitekturnya yang indah hal ini disebakan oleh beberapa faktor, seperti keadaan alam dan pengaruh budaya luar. Rumah Limas, Rumah Gudang dan Rumah Limas Gudang di Kota Palembang yang merupakan jenis rumah panggung memiliki adaptasi yang sangat baik dengan kondisi alam Palembang yang merupakan dataran rendah serta sebagian besar dipengaruhi pasang surut sungai Musi (Siswanto, 2009:37).

Berdasarkan latar belakang masalah di atas bahwa Jawa dan Melayu Sumatera Selatan memiliki kesamaan pada aspek kebudayaan dan arsitekturnya, maka peneliti bermaksud untuk melakukan penelitian dengan judul "Tinjauan Historis Hubungan Jawa-Melayu dalam Dunia Arsitektur Melayu Sumatera Selatan Sebagai Materi Pembelajaran Sejarah".

\section{B. METODE PENELITIAN}

Penelitian ini menggunakan penelitian deskriptif kualitatuf, yaitu penelitian yang berfokus pada sumber-sumber alamiah di mana penelitian ini adalah sebagai instrumen kunci, pengambilan sampel sumber data dilakukan secara purpoposive dan snowbaal, teknik pengumpulan data dengan triangulasi (gabungan), analisis data bersifat induktif/kualitatif, dan hasil penelitian kualitatif lebih menekankan makna dari pada generilisasi, dan dalam penelitian kualitatif ada 3 hal yang digambarkan dalam penelitian ini, yaitu karakteristik, perilaku kegiatan, atau kejadian yang terjadi selama penelitian dan keadaan lingkungan atau karakteristik tempat penelitian (Sugiyono, 2018:15).

\section{Teknik Pengumpulan Data \\ Survei Lapangan}

Metode survei lapangan ini dimaksud untuk mengamati dan melihat secara langsung keadaan tempat yang akan diteliti. Metode survei adalah metode yang digunakan untuk mendapatkan data dari tempat tertentu dengan cara melakukan perlakuan dalam pengumpulan data, misalnya dengan mengedarkan kuesioner (Sugiyono, 2015).

\section{Wawancara Mendalam}

Wawancara mendalam merupakan proses menggali informasi secara mendalam, terbuka, dan bebas dengan masalah dan fokus penelitian dan diarahkan pada pusat penelitian. Wawancara digunakan sebagai teknik pengumpulan data apabila peneliti ingin melakukan studi pendahuluan untuk menemukan permasalahan yang harus diteliti, dan juga apabila peneliti ingin mengetahui halhal diresponden yang lebih mendalam dan jumlah respondennya sedikit (Moleong, 2005:186).

Wawancara mendalam merupakan suatu kegiatan bertanya untuk menggali sebuah informasi dalam memenuhi hasil pembahasan penelitian.

\section{Pencatatan Dokumen (Studi Dokumen)}

Studi dokumen adalah sebuah cara dalam melakukan pengumpulan data, dengan 
menyimpan atau mengumpulkan sumber berupa dokumen yang berhubungan dengan tujuan penelitian. Studi dokumen adalah suatu cara untuk mengumpulkan data dengan mengadakan penyelidikan/menelaah yang ditunjuk pada penguraian dan penjelasan apa yang telah lalu, melalui sumber-sumber dokumen (Surakhmad, 1982:132).

\section{Studi Pustaka}

Studi pustaka adalah suatu karangan ilmiah yang berisi pendapat berbagai pakar mengenai suatu masalah, yang kemudian ditelaah dan dibandingkan, dan ditarik kesimpulannya. Seperti layaknya suatu karangan ilmiah, studi kepustakaan pun terdiri dari bagian pembuka, bagian tubuh/isi dan bagian penutup (Haryanto, 2000:76).

\section{Teknik Analisis Data}

Teknik analisis data merupakan cara mengolah data yang telah diperoleh dari lapangan. Hasil analisis data ini merupakan jawaban atas pertanyaan masalah. Teknik analisis data harus disesuaikan dengan jenis penelitian. Berdasarkan hal tersebut, teknik analisis data dibagi atas dua macam teknik, yakni analisis data secara kuantitatif dan teknik analisis data secara kualitatif (Maryati, 2001).

Dalam penelitian kualitatif ini, teknik analisis data yang digunakan penulis adalah teknik analisis data deskriptif kualitatif, yang diarahkan untuk menjawab rumusan masalah atau menguji hipotesis yang telah dirumuskan dalam proposal. Dalam penelitian kualitatif, data diperoleh dari berbagai sumber, dengan menggunakan teknik pengumpulan data yang bermacam-macam (triangulasi) dan dilakukan secara terus menerus sampai datanya jenuh (Sugiyono, 2015:333).

\section{HASIL DAN PEMBAHASAN \\ Sejarah Bangsa Melayu}

Migrasi bangsa Austronesia ke

Nusantara merupakan migrasi terakhir mereka dari Taiwan. Melalui jalur utara, migrasi Austronesia melewati Filipina sampai ke Sulawesi, Kalimantan. Kemudian, bangsa Austronesia lanjut menyebar hingga ke Madagaskar melalui Sumatera. Tidak heran apabila terdapat pengaruh sansekerta dalam bahasa yang dimiliki bangsa Manyan di Madagaskar (UI, 2018).

Sejarah perdagangan di Nusantara sudah terjadi ribuan tahun yang lalu. Perdagangan ini disebut juga dengan perdagangan kuno. Kebudayaan Dongson adalah kebudayaan yang sudah ada sejak zaman perunggu yang berkembang di Vietnam. Kebudayaan ini masuk ke Nusantara pada masa 1000 SM sampai 1 SM. Kebudayaan ini merupakan hasil dari bangsa Austronesia. Adapun peninggalan dari kebudayaan Dongson yang ditemukan di Nusantara:

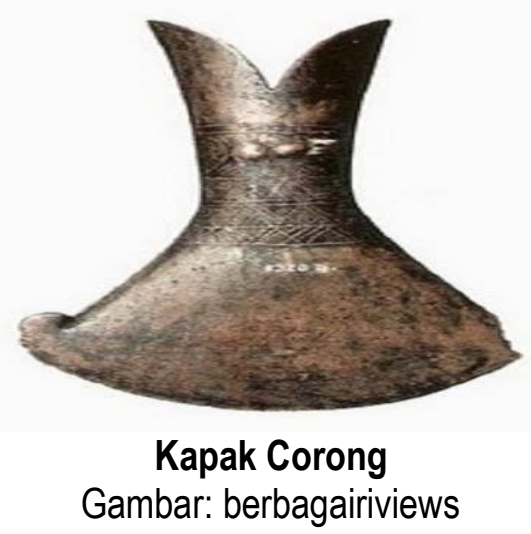

Kapak corong merupakan peninggalan kebudayaan Dongson yang tersebar hampir seluruh Nusantara. Selain kebudayaan Dongson pada masa yang sama juga terdapat budaya hasil dari bangsa Austronesia yang disebut dengan kebudayaan Shayun Kalanay, kebudayaan ini masuk ke Nusantara dan meninggalkan peninggalan kebudayaan seperti:

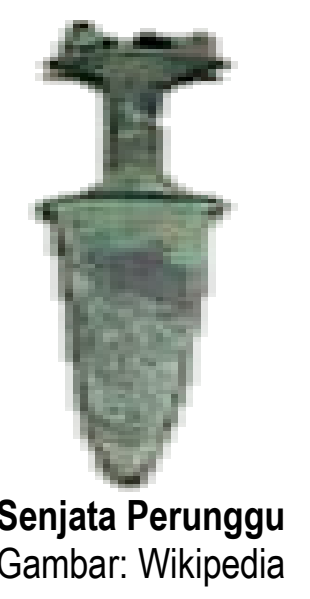


Senjata ini dibuat dari bahan perunggu, biasa digunakan oleh bangsa Austronesia dan ditemukan disebagian daerah di Nusantara. Suku Melayu adalah kelompok etnis Austronesia yang menghuni Semenanjung Malaya, seluruh Sumatera, bagian Selatan Thailand, Pantai Selatan Burma, Singapura, Borneo dan masih banyak lagi tempat singgahannya. Dalam perkembangannya, hampir seluruh Kepulauan Nusantara mendapatkan pengaruh dari suku Melayu ini (Barnar, 2004:7).

Hubungan kerajaan Melayu dengan bangsa luar dimulai dengan bangsa India yang banyak memberikan pengaruh terhadap kebudayaan bangsa Melayu. Tak hanya bangsa India, orang-orang Cina dan Asia Tenggara juga behubungan dengan orang-orang Malayu. Bangsa Melayu berhasil di Indianisasi dengan berkembangnya agama Hindu dan Buddha yang merupakan agama yang berasal dari India. Kerajaan Sriwijaya yang merupakan kerajaan Melayu yang bercorak Buddha.

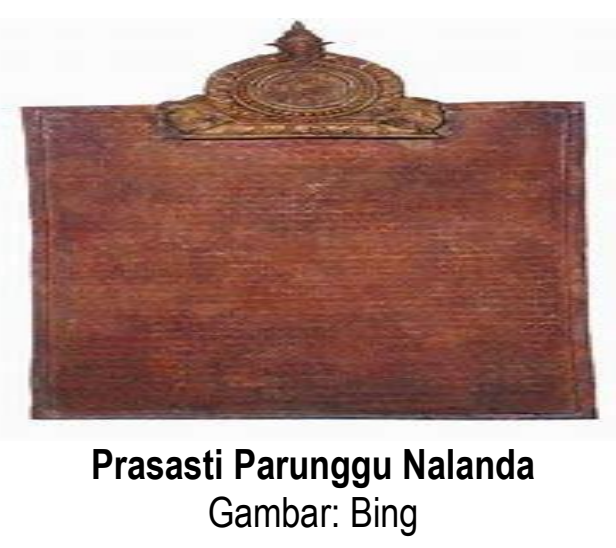

Prasati ini sebagai bukti bahwa Kerajaan Sriwijaya pernah berhubungan dengan bangsa India, dimana raja Balaputeradewa pernah dikatakan di dalam prasasti ini.

\section{Tinjauan Historis Hubungan Jawa-Melayu Sumatera Selatan pada Masa Klasik Hindu- Buddha}

Kerajaan Sriwijaya merupakan kerajaan Melayu terbesar dan terkuat pada bidang kelautan. Kerajaan ini berpusat di Kota Palembang, hal ini dikarenakan banyaknya bukti temuan prasasti Sriwijaya yang ditemukan di kota ini. Sriwijaya merupakan kedatuan hal ini dapat dibuktikan pada banyak prasati Sriwijaya yang menyebutkan tentang kedatuan salah satunya Prasasti Kota Kapur yang berisikan sumpah dari Dapunta Hyang terhadap masyarakat Kota Kapur jika melanggar sumpahnya akan terkena musibah.

Kerajaan Sriwijaya yang merupakan kerajaan maritim terbesar pada saat itu membuatnya mampu melakukan hubungan keberbagai daerah di Indonesia. Di masa yang sama di Jawa terdapat sebuah kerajaan besar yang bernama Mataram Kuno, dipegang oleh Wangsa Syailendra. Wangsa Syailendra sendiri menjadi bagian dari kerajaan Sriwijaya di mana dinasti ini berasal dari Kerajaan Mataram Kuno. Munculnya keterkaitan antara Sriwijaya dengan dinasti Syailendra dimulai karena adanya nama Śailendravamśa pada sebagian prasasti di antaranya pada prasasti Kalasan di Pulau Jawa, prasasti Ligor di Selatan Thailand, dan prasasti Nalanda di India. Sementara pada prasasti Sojomerto ditemukan nama Dapunta Syailendra. Prasasti Sojomerto ini ditulis dalam bahasa Melayu Kuno, dan bahasa Melayu umumnya digunakan pada prasasti-prasasti di Sumatera, maka diduga wangsa Syailendra berasal dari Sumatra, walaupun asal usul bahasa Melayu ini masih menunggu penelitian sampai sekarang (Poesponegoro, 1992).

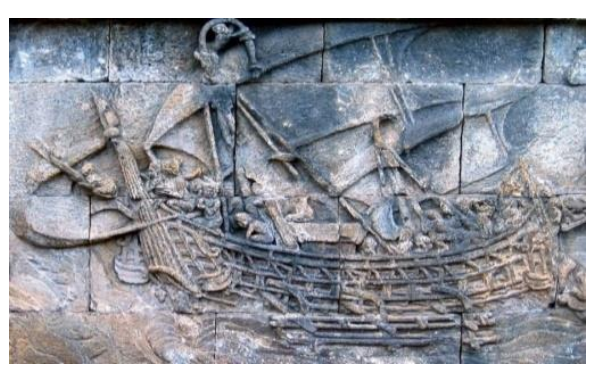

Relief Kapal Jung

Gambar: Kemendikbud

Relief Kapal Jung pada candi Borobudur yang didirikan oleh wangsa Syailendra yang merupakan kapal yang sering digunakan berlayar oleh Sriwijaya, hal ini menunjukan adanya hubungan antara Sriwijaya dengan Mataram Kuno.

Kerajaan Sriwijaya runtuh setelah mendapat serangan dari Kerajaan Chola India Selatan, selain itu juga disebabkan oleh kondisi alam yang tidak mendukung, hal ini 
menyebakan Kerajaan Sriwijaya tidak memiliki produk untuk dijual, namun faktanya kerajaan ini hancur di tahun 1377 karena diserang oleh Kerajaan Majapahit (Prinada, 2021).

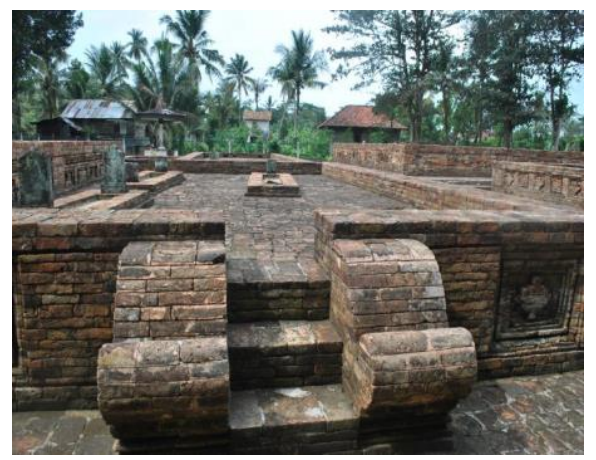

Bangunan Ki Gede Ing Suro Gambar: Trevelingyuk

Dari bentuk bangunan makam yang mirip candi tersebut memiliki pengaruh Jawa. Hal ini dibuktikan adanya bentuk pagar candi yang bercorak Hindu. Di makam ini juga ditemukan beberapa arca: 4 arca Buddha dan 1 arca Boddhisatwa masa Syailendra Kerajaan Mataram Kuno dan 3 arca Trimurti bercorak Majapahit. Temuan ini ditemukan oleh Schnitger yang ditemukan pada tahun 1935 ditemukan juga sebuah fragmen kepala makara yang terbuat dari Traktora. Temuan lepas di situs ini terdiri dari struktur bata (berprofil), manik-manik, benda berbahan perunggu dan alat pertanian (alu dan gandik) (Soeroso, 1997).

Berdasarkan temuannya komplek candi ini sudah menjadi tempat sakral masa Kerajaan Sriwijaya dibuktikan dengan temuan pondasi batu alam disekitar situs percandian oleh Bonson. Namun pengaruh Jawa mulai masuk ke Palembang sejak masa abad ke-13 $\mathrm{M}$ hingga abad 15 M (Sani, 1983).

Tinjauan Historis Hubungan Jawa-Melayu Sumatera Selatan pada Masa Klasik Islam

Runtuhnya Kerajaan Sriwijaya di abad ke-12 M, kota ini tetap eksis sebagai kota niaga yang di dalamnya terdapat tumpuan kegiatan ekonomi dan perdagangan yang masih dikenal Ku-Kang (dalam bahasa Cina) atau pelabuhan lama. Ketika Palembang dalam kontrol ekonomi Cina, Pangeran Palembang, Parameswara terpaksa meninggalkan kota ini di tahun 1397. Pada saat itu Majapahit tidak bisa meletakan adipatinya di kota ini dikarenakan Palembang dalam kontrol Cina sudah memilih pemimpinnya yang disebut Liang Tau Ming sebagai pimpinan Palembang. Namun pada masa Cina ini juga Palembang menjadi sarangnya para bajak laut Cina yang menyebabkan permasalahan akut di kota ini (Darussalam, 2019).

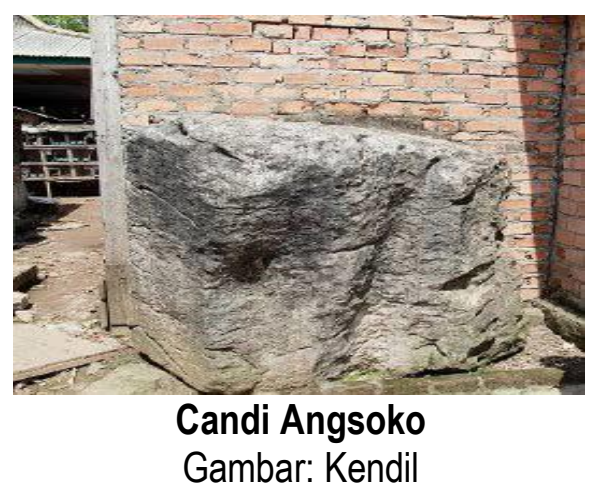

Berdasarkan hasil penelitian Balai Arkeologi Palembang menyatakan bahwa situs makam Angsoko menunjukan adanya temuan masa klasik yang lebih tua dari Islam. Temuan itu berdasarkan struktur bata yang merupakan bagian candi, fragmen keramik dan tulisan huruf Jawa Kuno yang diperkirakan abad ke-9 M sampai dengan abad ke-10 M (Hermawan, 2020:66).

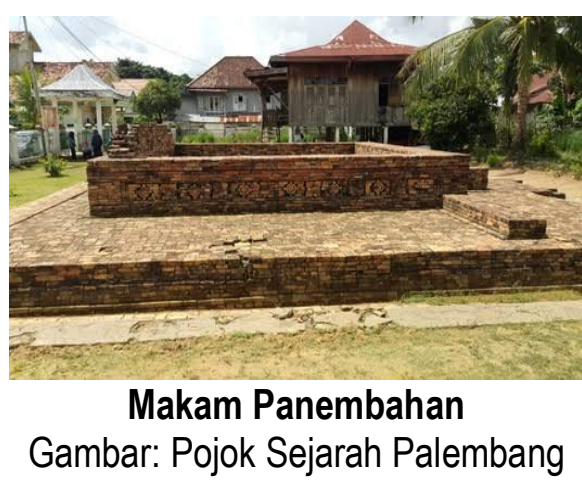

Makam ini terletak tidak jauh dari makam Ki Gede Ing Suro. Bentuk bangunan tidak jauh berbeda dengan makam Ki Gede Ing Suro, di dalam bangunan terdapat 2 makam. Bangunan ini berbentuk persegi empat dan tersusun atas 10 lapis bata. Di atas susunan bata terdapat 1 buah lapis batu gamping (Balai Pelestarian Peninggalan Purbakala Jambi Wilayah Kerja Provinsi Jambi, 2016). 


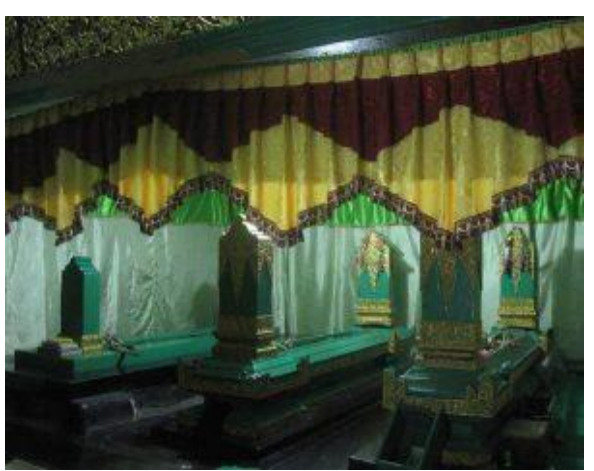

Makam Sabokingking

Gambar: Palembang Tourism

Makam ini terletak dikawasan 1 lir Palembang, makam ini diperkirakan sudah diketahui sebelum masa Islam Palembang tepatnya pada masa Sriwijaya abad ke-7 Masehi (Hermawan, 2020:67).

Di makam ini ditemukan Prasasti Telaga Batu yang merupakan peninggalan prasasti masa Kerajaan Sriwijaya. Selain itu pada sekitaran makam ditemukan juga Arsana yang merupakan batu yang digunakan sebagai dudukan arca dan prasasti. Selain unsur Sriwijaya pada kawasan makam ini juga memiliki unsur kesultanan, di mana isi dari makam tersebut merupakan para tokoh Kesultanan Palembang yang hidup di masa awal kesultanan abad ke-16 M (Balai Pelestarian Peninggalan Purbakala Jambi Wilayah Kerja Provinsi Jambi, 2016).

\section{Keraton-keraton Kesultanan Palembang}

Keraton Kuto Gawang merupakan keraton yang pernah berkuasa sekitar 100 tahun di Palembang. Keraton ini dibangun oleh $\mathrm{Ki}$ Gede Ing Suro, keraton ini dianggap sebagai pusat kekuatan magis. Keraton ini merupakan pusat dari Batanghari Sembilan, yang menjadi simbol kosmologi "Satu" yaitu dalam konsep Jawa-Melayu menjadi simbol penggambaran delapan buah penjuru mata angin yang pusatnya adalah kesembilan dan terletak di Keraton Palembang.

Di keraton ini para penguasanya melakukan adaptasi dengan lingkungan di sekitarnya sehingga terciptalah akulturasi dan asimilasi kebudayaan Jawa-Melayu dan dikenal dengan Kebudayaan Palembang. Sebelum masa kesultanan, daerah ini sangatlah strategis di mana wilayah ini dikelilingi sungai-sungai mulai dari arah Utara, Selatan, Timur hingga Barat. Keraton ini diperkirakan dikelilingi oleh pagar kayu tebal. Lokasi ini sekarang dijadikan PT Pusri BUMN (Trijayafmplg, 2017).

Pada tahun 1659 Kuto Gawang hancur oleh VOC, oleh Abdurrahman kekuasaan Kuto Gawang dipindahkan ke daerah Beringin Junggut yang letaknya sekarang di Jalan Masjid Lama Lorong Segaran atau dekat dengan Pasar 16 llir saat ini. Informasi tentang keraton ini tidak banyak data yang menjelaskan keberadaan keraton ini (Poesponegroho, 1992).

Keraton Beringin Janggut pada akhirnya runtuh dan dipindahkan ke Keraton Cerancangan yang letaknya berada di belakang Keraton Beringin Janggut. Tidak banyak data yang tersimpan mengenai keraton ini, namun keraton ini sendiri dibangun oleh anak dari Abdurahman yang merupakan pendiri Keraton Beringin Janggut. Sama halnya dengan keraton sebelumnya keraton ini juga ikut hancur dan dipindahkan ke Kuto Lamo atau Keraton Kuto Tengkuruk.

Keraton ini berdiri di sisi sebelah Barat dari istana ketiga, keraton ini juga dipisahkan oleh sungai Tengkuruk yang sekarang sudah ditimbun untuk pembangunan. Kuto Tengkuruk hancur oleh Belanda, di mana Belanda bertujuan untuk membangun rumah dinas yang diperuntukan bagi residen atau pimpinan Belanda di Palembang. Sekarang rumah residen ini menjadi sebuah museum dengan nama Museum Sultan Mahmud Badaruddin II (Genpi, 2019).

Setelah Beringin Junggut hancur, keraton dipindahkan kembali ke Kuto Besak. Keraton ini dipindah oleh Sultan Mahmud Badaruddin I Jayo Wikramo yang memerintah selama 34 tahun tepatnya dari tahun 1724-1758. Dimasanya Palembang terus mengalami peningkatan pembangunan, di antaranya bangunan makam Lemabang atau Kawah Tekurep, Kuto Batu (Kuto Lamo), Masjid Agung dan terusan-terusan kanal disekitaran Kota Palembang dan kampung. Dimasanya pula Palembang membangun sebuah benteng yang besar dan kuat yang disebut dengan Banteng Kuto Besak atau sekarang lebih dikenal BKB (Management Plan Pelestarian Kota Pusaka: Palembang, 2016). 


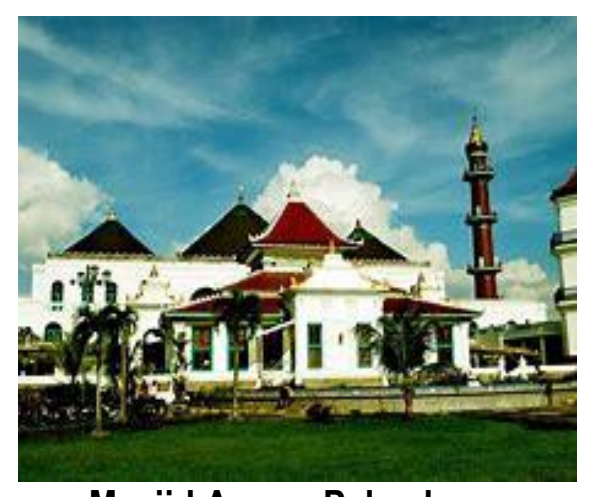

Masjid Agung Palembang

Gambar: kaskus

Masjid ini memiliki 3 gaya arsitektur yaitu Indonesia, Cina dan Eropa hal ini dikarenakan pada masa pembuatan budaya-budaya tersebut memang sedang berkembang pada saat itu. Pola bangunan utama berundak tiga dengan puncaknya limas. Undakan ketiga menjadi puncak masjid atau mustaka berukiran bunga tropis. Pada bagian ujung mustaka terdapat mustika berpola bunga merekah. Bentuk undakan bangunan masjid sendiri dipengaruhi oleh bangunan dasar candi Hindu-Jawa, yang kemudian diserap oleh Masjid Agung Demak. Ciri arsitektur Eropa terdapat pada bentuk jendela yang besar dan tinggi, materialnya pun dibawa langsung dari Eropa seperti marmer dan kaca. Bentuk pengaruh dari Cina bisa kita temukan pada bentuk atapnya yang berbentuk limas yang terdiri dari tiga tingkat. Terdapat bentuk seperti tanduk kambing melengkung, 13 juraian melengkung dan lancip, rupa ini merupakan bentuk atap kelenteng (Ardiwidjaja, 2020).

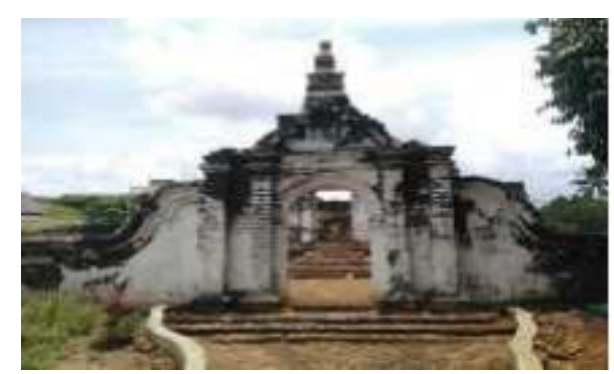

Makam Ki Ranggo Wirosentiko

Gambar: Riki Andi Sapotro

Orang yang di makam di komplek pemakaman ini adalah Ki Ranggo Wirosentiko yang merupakan tokoh berpengaruh di masa Kesultanan Palembang Darussalam. la berperan penting dalam pembangunan kota dan sistem pertanahan pada saat itu. Komplek pemakaman ini dulunya merupakan komplek percandian Hindu dari masa Sriwijaya abad ke$9 \mathrm{M}$. Sisa dari peninggalan itu bisa kita lihat pada bagian kaki candi. Sedangkan badan candinya mengalami kerusakan baik secara alami dan kesengajaan (Idris, 2019). Maka dapat dikaitkan komplek ini menjadi tempat penting bagi umat Buddha masa Sriwijaya.

\section{SIMPULAN}

Berdasarkan hasil penelitian dan pembahasan yang telah diterangkan sebelumnya, hubungan Jawa-Melayu dalam dunia arsitektur Melayu Sumatera Selatan dapat disimpulkan bahwa hubungan antara orang Jawa dengan Melayu Sumatera Selatan sudah lama dilakukan, terutama pada masa Sriwijaya hingga masa Kesultanan Palembang Darussalam. Adapun hubungan itu bisa kita lihat dari peninggalan arsitekturnya di Sumatera Selatan. Makam Ki Gede Ing Suro dan Panembahan mendapat pengaruh Jawa yaitu Kerajaan Majapahit. Selanjutnya ada Makam Candi Angsoko yang mendapat pengaruh dari Majapahit, Masjid Agung Palembang mendapat pengaruh dari candi di Jawa dan Kerajaan Demak, dan makam Ki Ranggo Wirosentiko yang juga mendapat pengaruh dari Kerajaan Jawa yang bisa temui adanya pengaruh Hindu pada bangunan makam.

\section{DAFTAR PUSTAKA}

\section{Buku}

Ardiwidjaja, R. 2020. Pariwisata Budaya. Ponorogo: Uwais Inspirasi Indonesia.

Barnar, T. P. 2004. Contesting Malayness: Malay Identity Across Boundaries. Singapore: Singapore University Press.

Farela, A. 2017. A Short history of Java. Surabaya: Ecosystem Publishing.

Hanafiah, D. 1995. Melayu-Jawa Citra Budaya dan Sejarah Palembang. Jakarta: PT Raja Grafindo Persada. 
Haryanto, \&. R. 2000. Metode Penulisan dan Penyajian Karya IImiah: Buku Ajar Untuk Mahasiswa . Jakarta: EGC.

Maryati, K. \&. 2001. Sosiologi Untuk SMA dan MA Kelas XII. Erlangga.

Moleong, L. 2005. Metodelogi Penelitian Kualitatif. Bandung: PT Remaja Rosdakarya.

Poesponegoro, M. D. 1992. Sejarah Nasional Indonesia: Jaman Kuno. Jakarta: PT Balai Pustaka.

Poesponegroho, M. D. 1992. Sejarah Nasional Indonesia: Jaman Petumbuhan dan Perkembangan Kerajaan-kerajaan Islam di Indonesia. Jakarta: PT Balai Pustaka.

Sani, N. 1983. Komplek Makam Gede Ing Suro di Palembang. Jakarta: Fakultas Sastra UI.

Sugiyono. 2015. Metode Penelitian Pendidikan Pendekatan Kuantitatif, Kualitatif, dan $R \& D$. Jakarta: Alfabeta.

Sugiyono. 2018. Metode Penelitian Kombinasi (MIx Methods). Bandung: Alfabeta.

Surakhmad, W. 1982. Pengantar Interaksi Belajar Mengajar, Dasar dan Teknik Metodologi Pengajaran. Bandung: Tarsito.

\section{Jurnal}

Balai Pelestarian Peninggalan Purbakala Jambi Wilayah Kerja Provinsi Jambi. 2016. Palembang.

Bakri, S. 2014. "Kebudayaan Islam Bercorak Jawa (Adaptasi Islam Kebudayaan Jawa)". Dalam Dinika. (33-39).

Faizaliskadiar, M. 1993. "Kadatuan Sriwijaya dalam Penelitian: Sebuah Pengantar Redaksi". Dalam Sriwijaya: dalam Perspektif Arkeologi dan Sejarah
Palembang. Pemerintah Tingkat 1 daerah Sumatera Selatan. (1-10).

Idris, Muhamad, dkk. 2019. "Akulturasi Budaya Hindu-Buddha dan Islam dalam Sejarah Kabudayaan Palembang". Dalam Kalpataru. Volume V, Nomor 2, Desember 2019.

Hermawan, W. 2020. "Cagar Budaya di Palembang Ilir Timur Sebagai Sumber Penulisan Buku Saku Sejarah di Palembang". Dalam Kalpataru, Volume VI, Nomot 1, 2020. (66).

Management Plan Pelestarian Kota Pusaka: Palembang, 2016.

Nurhidayah, M. 2019. "Analisis Terhadap Eksistensi Budaya Unggah-Ungguh Suku Jawa Dikalangan Remaja di Desa Srikaton Kecamatan Air Salek di Kecamatan Banyuasin Palembang". Dalam Sriwijaya University.

Siswanto, A. 2009. "Kearifan Lokal Arsitektur Tradisional Sumatera Selatan Bagi Pembangunan Lingkungan Binaan". Dalam Local Wisdom. (37-45).

Soeroso. 1997. "Situs Gede Suro: Lampiran dan Foto". Dalam Laporan Penelitian Arkeologi Palembang. Palembang: Balai Arkeologi Palembang. (tidak di publikasikan).

\section{Internet}

Genpi. 2019. "Ini 5 Keraton Palembang Darussalam". Dalam Genpi. https://www .google.com/ amp/s/www.henpi.co/amp /berita /6353 /ini-5-keraton-palembangdarussalam/ diakses pada Rabu, 16 Juni 2021.

Prinada, Y. 2021. "Sejarah Runtuhnya Kerajaan Sriwijaya dan Silsilah Raja-raja”. Dalam Tirto.

https://www.google.com/amp/s/amp.tirto. id/sejarahruntuhnya-kerajaan-sriwijaya- 
silsilah-raja-raja f9nv/ diakses pada

Selasa, 6 April 2021, pukul 13.00 WIB.

Darussalam, S. K. 2019. "Sejarah Kesultanan

Palembang Darussalam". Dalam Indhepedia. https://www.Indephedia . com /2019 /01 / sejarahkesultananpalembang-darusslam.html? $\mathrm{m}=1$ diakses pada 06 April 2021 pukul 12.00 WIB.

Trijayafmplg. 2017. "Kuto Cerancangan Keraton Palembang yang Hilang". Dalam Net Berita. http://trijayafmplg.net/berita/ 2017/10/kuto-cerancangan-keraton palembang-yang-hilang/ diakses pada Selasa, 6 April 2021 Pukul 12.00 WIB.

UI, F. 2018. "Jejak Migrasi Austronesia dan Pengaruhnya". Dalam FISIP UI. httpsfisip.ui.ac.id/kuliah-umum-profjames-fox-bahas-migrasi-austronesiadan-pengaruhnya/ diakses pada Senin, 5 April 2021, pukul 11.00 WIB. 


\section{KETENTUAN PENULISAN ARTIKEL JURNAL KALPATARU}

1. Naskah berbahasa Indonesia yang disempurnakan bertemakan kesejarah yang meliputi hasil penelitian sejarah, pengajaran sejarah dan penelitian kebudayaan.

2. Naskah harus asli dan belum pernah dimuat dalam media lain. Naskah dapat berupa hasil penelitian/artikel kajian konseptual yang ditulis oleh perorangan dan atau kelompok.

3. Naskah ditulis dengan cara-cara yang sesuai dengan ketentuan penulisan artikel ilmiah menggunakan bahasa Indonesia yang baku, berupa ketikan, beserta soft file dalam CD-RW atau dengan mengirimkan email pada redaksi jurnal Kalpataru dengan alamat jurnalkalpatarusejarah@gmail.com, spasi tunggal, jenis huruf arial narrow ukuran 12, dengan panjang naskah antara 8-15 halaman pada kertas A4.

4. Artikel hasil penelitian memuat:

JUDUL

Nama Penulis

Abstrak

A. PENDAHULUAN

B. METODE PENELITIAN

C. HASIL DAN PEMBAHASAN

D. SIMPULAN

DAFTAR PUSTAKA

\section{: XXX (HURUF KAPITAL)}

: (disertai jabatan, institusi, dan email)

: (Bahasa Indonesia yang memuat 100-200 kata diikuti kata kunci, dengan jenis huruf arrial narrow dan ukuran huruf 11 serta dicetak miring).

: (memuat latar belakang masalah, tinjauan pustaka secara ringkas, masalah penelitian, dan tujuan penelitian).

: (berisi simpulan).

: (berisi pustaka yang dirujuk dalam uraian naskah).

5. Artikel Kajian Konseptual memuat:

\section{JUDUL \\ Nama Penulis \\ Abstrak \\ PENDAHULUAN \\ Sub Judul \\ Simpulan \\ DAFTAR PUSTAKA}

\section{: XXX (HURUF KAPITAL)}

: (disertai jabatan, institusi, dan email)

: (Bahasa Indonesia yang memuat 100-200 kata diikuti kata kunci, dengan jenis huruf arrial narrow dan ukuran huruf 11 serta dicetak miring.

: (memuat latar belakang masalah, tinjauan pustaka secara ringkas, masalah penelitian, dan tujuan penelitian).

: Sesuai dengan kebutuhan (tanpa numbering).

: (berisi simpulan dan saran).

6. Referensi sumber dalam teks artikel ditulis dengan menggunakan side note, contoh (Jalaludin, 1991:79); sementara penulisan daftar pustaka disusun dengan ketentuan. Nama pengarang. Tahun terbit. Judul (dicetak miring). Kota terbit: Nama Penerbit. Contoh: Koentjaraningrat. 2010. Manusia dan Kebudayaan di Indonesia. Jakarta: Djambatan. Daftar pustaka hanya memuat pustaka/sumber yang dirujuk dalam uraian dan disusun menurut abjad tanpa nomor urut.

7. Naskah yang dimuat akan disunting kembali oleh redaksi tanpa mengubah isinya.

8. Naskah yang ditolak (tidak bisa dimuat) akan dikirim kembali ke penulis dengan pemberitahuan tertulis dari redaksi atau melalui email.

9. Penulis yang naskahnya dimuat akan mendapat 1 (satu) majalah nomor yang bersangkutan.

10. Kontak person: Muhamad Idris (081271498618); Eva Dina Chairunisa (082281267851); Jeki Sepriady (085269261780). 